\title{
EDUKASI UNICORN START-UP DI ERA DIGITAL 4.0 SEBAGAI SARANA PROMOSI PRODUK UMKM DI KELURAHAN CIWADUK (MITRA GO-JEK)
}

\author{
Eva Safaah \\ safaah.unsera@gmail.com \\ Dentik Karyaningsih \\ karya.tiek@gmail.com \\ Eva Fachriyah \\ fahriyaheva@gmail.com
}

\section{UNIVERSITAS SERANG RAYA}

\begin{abstract}
ABSTRAK
Kegiatan pengabdian ini bertujuan untuk mengenalkan, mengedukasi dan membantu para pelaku bisnis Usaha Mikro Kecil Menengah (UMKM) produk pangan dalam mempromosikan produk makanan lokal secara online bekerjasama dengan Kelurahan Ciwaduk. Metode kegiatan pengabdian yang dilakukan yakni metode study kasus, pengambilan data dengan cara wawancara langsung, observasi langsung di lokasi pengabdian dan dokumentasi kegiatan. Kegiatan pengabdian melibatkan Bapak Lurah Ciwaduk, Kepala Seksi Pemberdayaan Masyarakat dan Kesejahteraan Sosial Kelurahan Ciwaduk, dan para pelaku UMKM produk pangan Kelurahan Ciwaduk sebanyak 30 orang para pelaku UKM yang bertempat di Kantor Kelurahan Ciwaduk, Kota Cilegon, Provinsi Banten. Strategi promosi penjualan produk UMKM makanan yang dilakukan adalah memanfaatkan aplikasi go-jek dengan cara menjalin kerjasama mitra Go-Jek dan mendaftarkan produk pangan yang dihasilkan sehingga lebih dikenal oleh masyarakat. Hasil dari kegiatan ini adalah Masyarakat teredukasi melalui pendidikan dan pelatihan nonformal sehingga mampu mempromosikan produk UKM yang dihasilkan secara digital. Membantu meningkatkan kemampuan kreativitas dan keterampilan masyarakat untuk digunakan dalam mempromosikan usaha-usaha baru. Produk lokal hasil UMKM Kelurahan Ciwaduk dapat dikenal masyarakat luas dan menjadi produk unggulan yang bernilai ekonomi, memberikan peluang usaha bagi masyarakat yang ingin memulai usaha makanan, dan Meningkatkan taraf hidup masyarakat.
\end{abstract}

Kata kunci: Ciwaduk, Pemasaran Digital, Produk Lokal, UMKM, Workshop.

\section{PENDAHULUAN}

Kegiatan pengabdian

ini dilatarbelakangi oleh sebagian besar masyarakat masih memasarkan produk yang dimiliki secara konvensional yaitu dipasarkan secara langsung. Selain itu, kurangnya pengetahuan masyarakat memasarkan produk UMKM yang dimiliki secara digital. Pemasaran digital sangat urgent untuk dilakukan khususnya di era perkembangan digital yang semakin pesat sekarang. Hasil yang diharapkan pada kegiatan pengabdian ini adalah masyarakat 
pelaku UKM terbekali pengetahuan dalam memasarkan produk UKM yang dihasilkan secara digital.

Aktivitas yang banyak dilakukan masyarakat Kota Cilegon diantaranya kegiatan industri, perdagangan, hotel dan restoran. Aktivitas tersebut merupakan sektor yang paling banyak menyerap tenaga kerja, sejumlah 33.116 tenaga kerja. Sektor Industri adalah sektor yang banyak di serap lapangan pekerjaan terbesar kedua di Kota Cilegon, yakni sekitar 24,68 \% atau sebesar 29.755 tenaga kerja.

Setiap Kegiatan pemasaran harus dimiliki oleh setiap pelaku usaha agar dapat terus mengembangkan usahanya dan memasarkan produknya. Kegiatan pemasaran adalah suatu proses kegiatan kemasyarakatan dan terstruktur yang di dalamnya terjalin interaksi antara individu dan kelompok sehingga mendapatkan apa yang mereka butuhkan dan inginkan dengan menciptakan, menawarkan, dan mempertukarkan produk yang memiliki nilai ekonomi dengan pihak lain (Kotler, 1997:8).

Pelaku usaha memiliki strategi pemasarannya masing-masing dalam memasarkan produk. Strategi pemasaran merupakan hal yang penting bagi para pelaku usaha, di mana strategi yang dimiliki para pelaku usaha merupakan cara untuk mencapai tujuan dari sebuah usaha. Strategi usaha di sini adalah serangkaian rancangan besar strategi yang menggambarkan bagaimana sebuah usaha harus beroperasi dalam mencapai tujuannya (Stanton, 1991: 5).

Perkembangan teknologi dan internet saat ini memudahkan pengguna smartphone, laptop dan tablet untuk memasarkan produknya secara luas secara digital. Hal ini merupakan peluang baru bagi para pelaku usaha untuk memasarkan produknya dengan luas. Para pelaku usaha harus segera menyesuaikan metode pemasarannya dan menjalin kerjasama dengan berbagai perusahaan yang ada (Kartajaya, 2008: 9).

Internet merupakan teknologi digital yang memiliki perkembangan yang cepat dan salah satu faktor yang mendukung perkembangan penjualan secara online saat ini. Jaringan global internet ini menghubungkan jaringan komputer di seluruh dunia, sehingga komunikasi dan interaksi dapat terjalin antara negara satu dengan negara lain.

Dengan memanfaatkan fasilitas internet, para pelaku UMKM dapat menjalin hubungan usaha dengan pelaku UMKM yang lain atau konsumen secara lebih efisien kapan saja dan di mana saja. Sampai saat ini internet merupakan infrastruktur yang paling ideal untuk menjalankan transaksi penjualan online khususnya para pelaku UMKM, sehingga istilah e-commerce pun menjadi identik dengan menjalankan usaha di internet.

Dengan jumlah pengguna internet yang mencapai angka 82 juta orang atau sekitar $30 \%$ dari total penduduk di Indonesia (Surata, 2015), pasar penjualan online menjadi kegiatan usaha yang sangat menarik bagi sebagian orang yang bisa melihat potensi usaha ke depannya khususnya para pelaku UMKM. Pertumbuhan transaksi digital ini didukung dengan data dari Menkominfo yang menyebutkan bahwa nilai transaksi penjualan online pada tahun 2013 mencapai angka Rp130 triliun.

Menurut (Siregar, 2010), Definisi Ecommerce (e-commerce) atau pemasaran digital adalah proses transaksi jual beli atau pertukaran barang, jasa dan informasi melalui jaringan internet. Pemasaran digital merupakan bagian dari e-business, di mana cakupan e-business lebih luas, tidak hanya sekedar perdagangan tetapi mencakup juga gabungan dari mitra usaha, pelayanan nasabah, lowongan pekerjaan dll.

Menurut Rahmati (2009), transaksi penjualan online yang dilakukan pada penelitiannya diantaranya adalah distribusi, transaksi jual beli, pemasaran dan aktifitas jasa yang menggunakan jaringan internet. Transaksi jual beli yang dilakukan merupakan gabungan transaksi antara jasa dan barang. Transaksi penjualan online dan kegiatan yang terkait melalui internet ini dapat menjadi penggerak untuk 
memperbaiki perekonomian masyarakat lokal dan mempercepat integrasi dengan kegiatan produksi yang mendunia.

Menurut (Kotler \& Armstrong, 2008: 245), Transaksi pemasaran digital adalah transaksi online yang melibatkan interaksi konsumen yang akan menghubungkan mereka lebih dekat ke transaksi pembelian langsung atau hasil pemasaran secara online.

Dari latar belakang yang di paparkan target yang ingin dicapai adalah melakukan sosialisasi pemasaran secara digital sehingga masyarakat terbekali bagaimana cara memasarkan produknya secara digital. Pada pengabdian yang dilakukan yaitu mensosialisasikan pemasaran digital dengan memanfaatkan platform go-jek.

\section{METODOLOGI PELAKSANAAN}

Pada kegiatan pengabdian ini melibatkan 30 peserta UMKM yang khususnya memiliki produk di bidang pangan atau kuliner. Kegiatan dilakukan dengan mengedukasi masyarakat (pelaku UMKM) bagaimana cara memasarkan produk secara digital dengan jaringan internet dengan memanfaatkan berbagai platform yang ada khususnya platform gojek.

Strategi Pemasaran dapat dilihat pada gambar 1.

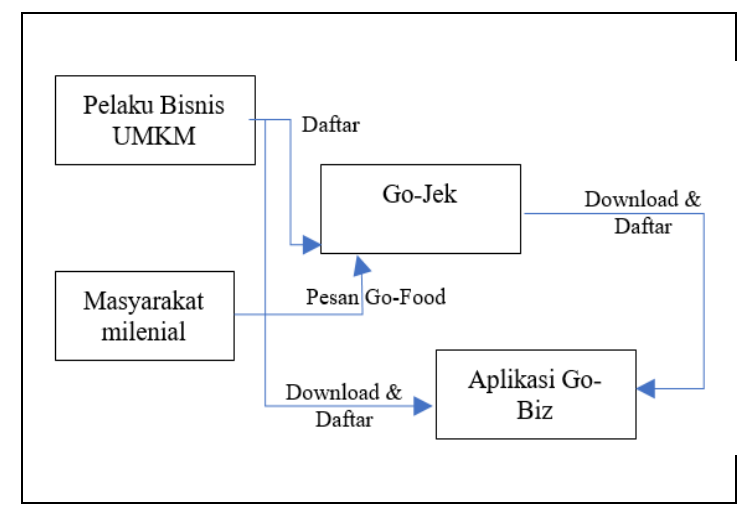

Gambar 1. Strategi Pemasaran Produk

UMKM Produk Pangan Kelurahan

Ciwaduk.

(Sumber: hasil penelitian, 2019)
Dari gambar 2 terlihat bahwa upaya promosi produk UMKM kelurahan Ciwaduk dilakukan dengan cara:

1. Datang langsung ke cabang kantor pusat Go-Jek yang berlokasi di daerah serang, Banten untuk mendaftarkan produk UKM berupa hasil pangan.

2. Mendownload aplikasi Go-Biz menggunakan telepon selular berbasis android dan mendaftarkan produk dagangan secara online.

Dari gambar tersebut, setelah produk UMKM terdaftar dan produknya tertera pada aplikasi Go-Food dengan ketentuan yang berlaku, maka masyarakat milenial dapat memesan dan menikmati produk UMKM yang ada di aplikasi Go-Food.

\section{HASIL DAN LUARAN}

Pelaksanaan kegiatan ini adalah dalam rangka turut berpartisipasi dalam kegiatan pelaksanaan dan pendidikan dan sosialisasi yang di adalan oleh Kelurahan Ciwaduk.

Kegiatan seminar ini dilakukan dengan mengedukasi para pelaku UMKM produk pangan agar produknya dapat dikenal oleh masyarakat luas. Sosialisasi pengenalan start-up unikorn dihadiri oleh para pelaku UMKM sebanyak 30 orang dan berlangsung selama 1 hari.

Kegiatan seminar ini dihadiri oleh sebagian ibu-ibu rumah tangga yang tergabung dalam kelompok UMKM daerah Kelurahan Ciwaduk.

Kegiatan diadakan di kelurahan Ciwaduk dan dihadiri oleh Lurah Ciwaduk yaitu Bapak Dedi Suryadinata, S.IP., Kepala Seksi Pemberdayaan Masyarakat dan Kesejahteraan Sosial, dan para pelaku UMKM kelurahan Ciwaduk, CilegonBanten.

Sosialisasi dilakukan dalam dua sesi yaitu sesi pemaparan dan sesi kedua yaitu diskusi dan tanya jawab. 


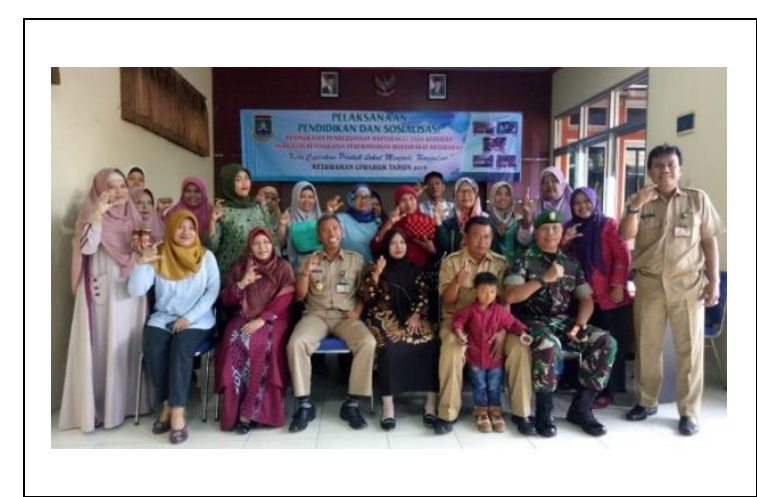

Gambar 2. Workshop Pengenalan Start-up Unikorn Sebagai Media promosi Produk UMKM.

Edukasi Promosi penjualan produk UMKM dilakukan dengan mengedukasi para pelaku bisnis agar menjalin mitra dengan aplikasi Go-Jek yaitu dengan mendownload aplikasi Go-Biz dan mendaftarkan produk UMKM secara GRATIS atau dengan datang langsung ke kantor pusat Go-Jek yang berlokasi cabang pusat di Daerah Serang, Banten.

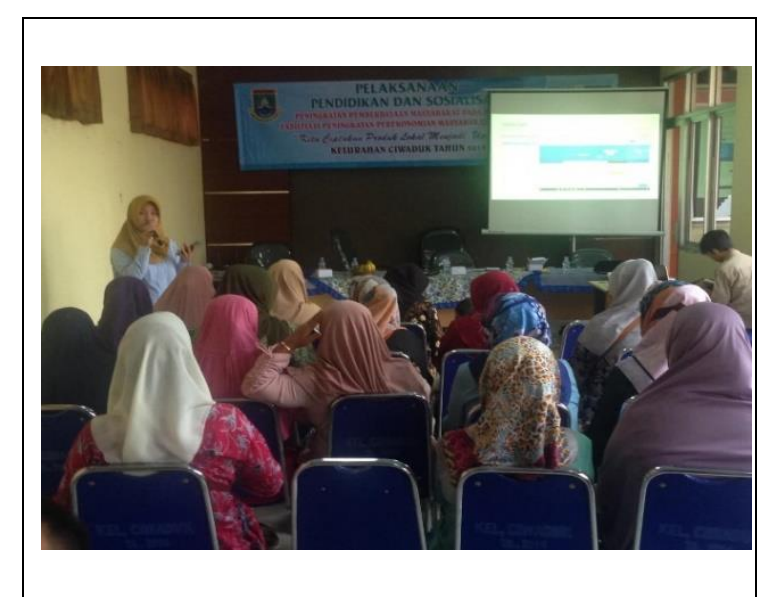

Gambar 3. Sesi Diskusi Promosi Produk UMKM.

Salah satu Produk lokal yang terdapat di Kelurahan Ciwaduk diantaranya adalah produk makanan kering seperti keripik kulit tangkil (Kulit Melinjo) yang dapat dilihat pada gambar 4.

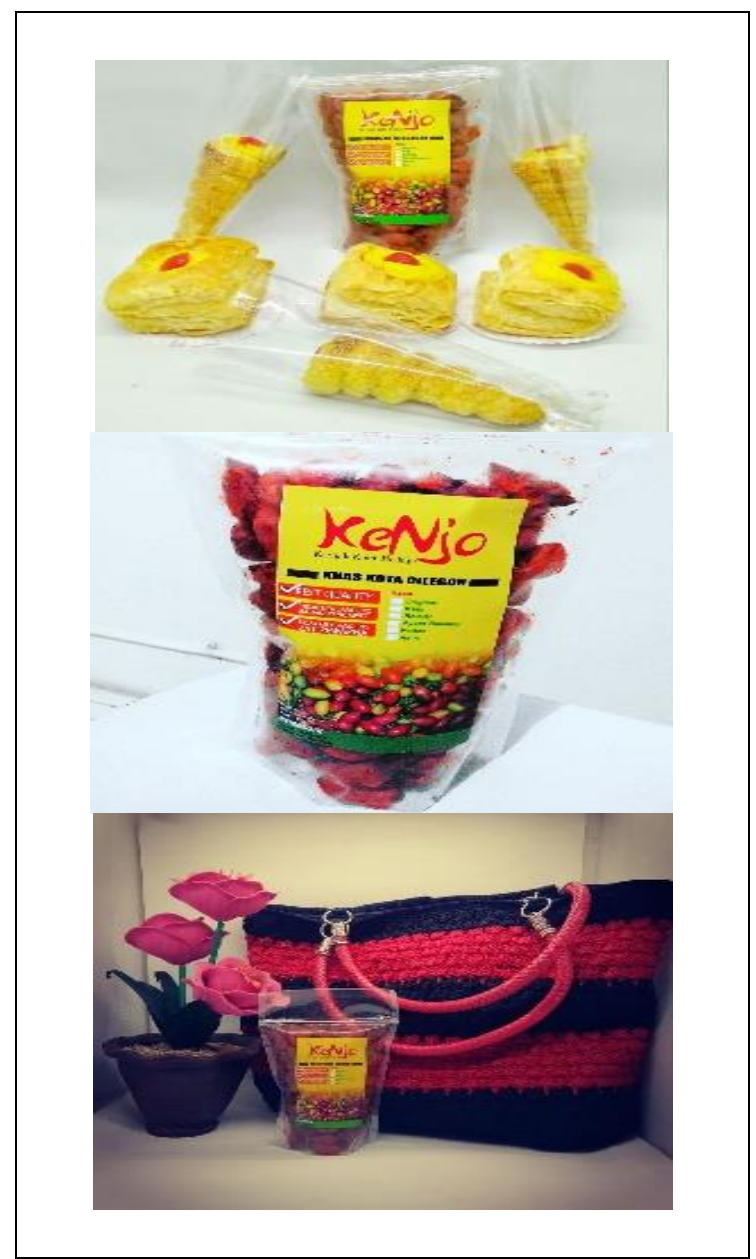

Gambar 4. Produk Lokal Kelurahan Ciwaduk.

Keripik Kulit Melinjo (KeNjo)

Berikut adalah hasil kuesioner yang telah di lakukan saat kegiatan adalah sebagai berikut:

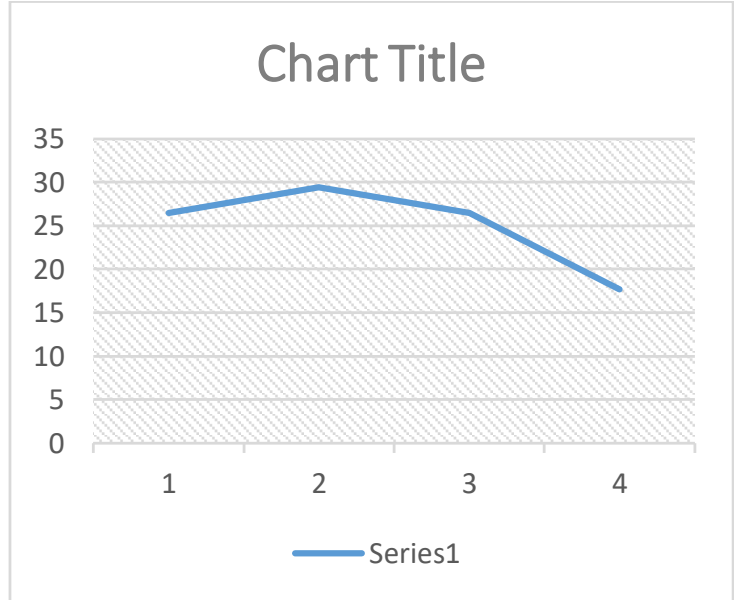

Gambar 5. Hasil Kuisioner Pre Test Edukasi Unicorn. 
Dari gambar 5 diperoleh bahwa:

1) $23.68 \%$ dari 20 peserta belum mengetahui tentang aplikasi go-jek.

2) $26.32 \%$ dari 20 peserta belum pernah menjual produk dagangannya menggunakan aplikasi go-jek.

3) $23.68 \%$ dari 20 peserta menginginkan pelatihan penjualan secara online.

4) $26.32 \%$ dari 20 peserta ingin membantu perekonomian di dalam keluarga.

Setelah dilakukan sosialisasi diperoleh tabel target capaian sebagai berikut:

Tabel. 1. Tabel Capaian Akhir Sosialisasi.

\begin{tabular}{|c|c|c|}
\hline Pertanyaan 1 & Angka & Persentase (\%) \\
\hline 1 & 15 & 11.36 \\
\hline 2 & 18 & 13.64 \\
\hline 3 & 20 & 15.15 \\
\hline 4 & 19 & 14.39 \\
\hline 5 & 20 & 15.15 \\
\hline 6 & 20 & 15.15 \\
\hline 7 & 20 & 15.15 \\
\hline Jumlah & $\mathbf{1 3 2}$ & $\mathbf{1 0 0}$ \\
\hline
\end{tabular}

Target capaian di atas di representasikan ke dalam gambar 6.

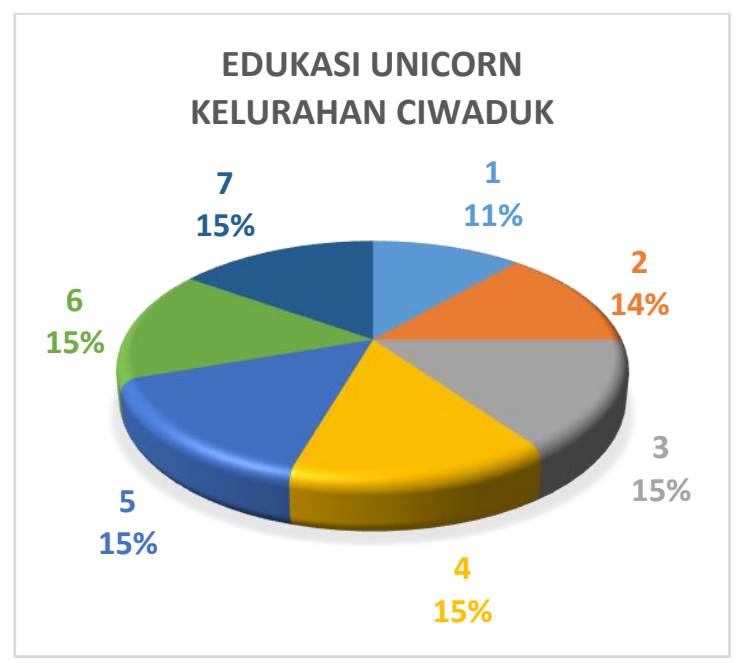

Gambar 6. Grafik Hasil Kegiatan Edukasi Unicorn.

Dari target hasil capaian yang telah diraih diantaranya adalah:
1. Masyarakat teredukasi melalui pendidikan dan pelatihan nonformal sehingga mampu mempromosikan produk UKM yang dihasilkan secara digital.

2. Membantu meningkatkan kemampuan kreativitas dan keterampilan masyarakat untuk digunakan dalam mempromosikan usaha usaha baru.

3. Produk Lokal hasil UMKM Kelurahan Ciwaduk dapat Dikenal Masyarakat Luas Dan Menjadi Produk Unggulan yang bernilai Ekonomi.

4. Memberikan peluang usaha bagi masyarakat yang ingin memulai usaha makanan.

5. Meningkatkan taraf hidup masyarakat khususnya ibu rumah tangga yang tidak bekerja

6. Mengoptimalkan peran ibu rumah tangga di berbagai bidang sehingga dapat membantu suami untuk menambah ekonomi atau pendapatan keluarga dengan UMKM.

7. Membuka peluang bisis bagi ibu rumah tangga yang ingin memulai usaha baru.

\section{KESIMPULAN DAN SARAN}

Hasil dari kegiatan ini adalah Masyarakat teredukasi melalui pendidikan dan pelatihan nonformal sehingga mampu mempromosikan produk UKM yang dihasilkan secara digital, Membantu meningkatkan kemampuan kreativitas dan keterampilan masyarakat untuk digunakan dalam mempromosikan usaha-usaha baru. Produk lokal hasil UMKM kelurahan Ciwaduk dapat dikenal masyarakat luas dan menjadi produk unggulan yang bernilai ekonomi. Memberikan peluang usaha bagi masyarakat yang ingin memulai usaha makanan, dan Meningkatkan taraf hidup masyarakat.

Kegiatan ini di dukung oleh Kelurahan Ciwaduk sebagai bentuk dukungan dari pemerintah terhadap kelompok Usaha Kecil 
Menengah. Hal ini terlihat dengan diadakannya kegiatan ini yang berlokasi di Kelurahan Ciwaduk.

Saran dari kegiatan ini adalah perlu adanya binaan yang berkelanjutan, seminarseminar dan workshop yang mendukung kegiatan para pelaku UMKM tentunya dengan adanya dukungan dari kelurahan setempat.

\section{UCAPAN TERIMA KASIH}

Penulis mengucapkan terima kasih kepada LPPM Universitas Serang Raya dan Fakultas Teknologi Informasi prodi Informatika atas dukungan penuh yang diberikan dan seluruh pihak yang telah mendukung dan terlibat selama kegiatan pengabdian ini berlangsung dan kepada seluruh pihak terkait yang tidak dapat disebutkan satu persatu.

\section{DAFTAR PUSTAKA}

Farida, I, Tarmizi, A, November, Y. (2016). Analisis Pengaruh Bauran Pemasaran 7P terhadap Kepuasan Pelanggan Pengguna Gojek Online. Jurnal Riset Manajemen dan Bisnis (JRMB) Vol.1, No.1.

Irmawati, D. (2011). Pemanfaatan ECommerce dalam Dunia Bisnis. Jurnal Ilmiah Orasi Bisnis Edisi KeVI.

Kotler, P. (1997). Manajemen Pemasaran, Alibahasa, Hendra Teguh, Ronny Antonius Rusli. Jakarta: Prenhallindo.

Kotler, P. \& Armstrong, G. (2008). Prinsipprinsip Pemasaran, Jilid 1 edisi kedua belas terjemahan. Jakarta: Erlangga.

Reza, F. (2016). Strategi Penjualan Online Lazada.co.id. Jurnal Kajian Komunikasi, Volume 4, No. 1.

Siregar, R.R. (2010). Strategi Meningkatkan Persaingan Bisnis Perusahaan dengan Penerapan E-commerce. http://blog.trisakti.ac.id/riki/2010/03/ 12/strategi-meningkatkanpersainganbisnis-perusahaan-dengan- penerapan-e-commerce/.

Diakses tanggal 01 Agustus 2011.

Stanton, J. (1991). Prinsip Pemasaran. Jakarta: Erlangga.

Suharo, Y. (2008). Keputusan Membeli Secara Online dan faktor-faktor yang Mempengaruhinya. Jurnal Teknologi Informasi DINAMIK Vol. 8, No.2.

Surata, I, N. (2015). Fantastis, pertumbuhan e-commerce di Indonesia Saat Ini. Diakses dari http://www. academia.edu/12166388/Fantastis_ Pertumbuhan_E-Commerce_di_ Indonesia_Saat_ini tanggal 12 Februari 2015.

Yin, K. (2012). Studi Kasus: Desain dan Metode. Jakarta: Rajawali Pers. 